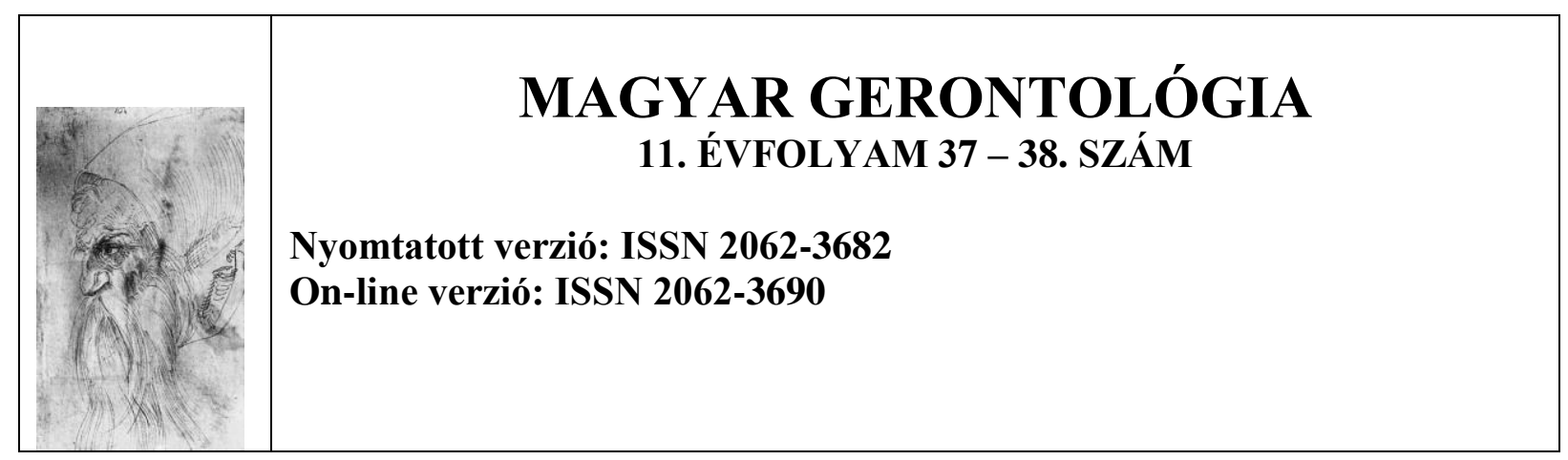

\title{
AZ AKTÍV IDŐSKOR SZEREPE A FOGYASZTÓVÉDELEMBEN
}

dr. Balázs Katalin ${ }^{1}$ - Bene Ágnes ${ }^{2}$

${ }^{1}$ Debreceni Egyetem, Pszichológiai Intézet

${ }^{2}$ Debreceni Egyetem, Egészségügyi Kar

Levelező szerző elérhetősége:

dr. Balázs Katalin Ph.D.

e-mail:balazs.katalin@arts.unideb.hu

telefon:06-52-512-900/22536, 06-20-456-85-93

\section{Összefoglalás}

Világszerte gyakoriak a megtévesztések, melyek kifejezetten az időseket célozzák (Boush, Friestad és Wright, 2009; Valant, 2015). Az aktív középkort követően számos fiziológiai, pszichológia változás megy végbe az idősödő személyekben. Ezek a változások persze nem mindenkinél azonos mértékủek. Az idősödő generáció képviselőinek tipikus kommunikációs és társas jellemzői képezik az alapját ezeknek az átveréseknek melyek etikátlanul visszaélnek a korosztály sérülékenységével. Az idősek általában befolyásolhatóbbak, mint a fiatalabb felnőttek (Visser és Krosnick, 1998).

A tanulmányban összefoglaljuk a szakirodalom alapján az idősek átverésekkel szembeni sérülékenységét megalapozó jellemzőket. Valamint beszámolunk egy idősek körében interjúmódszerrel végzett vizsgálatról, melyben a válaszadók gyanús megkeresésekkel kapcsolatos tapasztalataikról számolnak be. 


\title{
Kulcsszavak: fogyasztóvédelem, aktív időskor, meggyőzés, átverés, sérülékenység
}

\section{THE ROLE OF ACTIVE AGEING IN THE CONSUMER PROTECTION}

\begin{abstract}
Worldwide recognized the high prevalence of deceit aimed at elderly individuals (Boush, Friestad és Wright, 2009; Valant, 2015). Following the active middle-age, aging individuals perceive several physiological and psychological changes. Naturally, these changes do show individual differences. The aging generation members' typical communication related and social features are to blame for these deceptions, unethical abuse of the vulnerability. Elderly individuals are more susceptible to persuasion than younger adults (Visser és Krosnick, 1998).

In the present study, we summarize features appeared in the literature which can establish older people's vulnerability. Furthermore, we report an interview-based-study, in which the examinees shared their experiences on suspicious offers.
\end{abstract}

\section{Keywords: consumer protection, active aging, persuasion, deception, vulnerability}

\section{Bevezetés}

Az Egészségügyi Világszervezet (WHO) besorolása alapján a 60 és 65 év fölöttieket időseknek nevezzük, míg az 50 év felettiek megnevezése: idősödő személyek. Az élettartam növekedésével, a társadalmaknak számos olyan problémával kell megküzdeniük, ami korábban nem volt jellemző (pl. Kalache, 2001). Azaz a várható élettartam növekedésének előnye összekapcsolódik új megoldásokat igénylő problémákkal is. Számos más kérdés mellett a szakirodalom felismerte az idősödő személyek fogyasztóvédelmi sérülékenységét is, Amerikában és Európában egyaránt (pl. Boush és mtsai, 2009; Valant, 2015).

Maga a sérülékenyég egy komplex konstruktum (Baker, Gentry, Rittenburg, 2005, 7. old.), ebben tanulányban sérülékenység alatt a személy fizikai állapotából, személyiségéből, és a helyzetből fakadó fokozott kiszolgáltatottságot értjük, eladási helyzetben. Általánosságban igaz az, hogy az idősebb felnőttek másként fogadják be a meggyőző üzeneteket, mint aktív korú társaik (Boush és mtsai, 2009; Campbell és Kirmani, 2008; Carpenter és Yoon, 2017); és kiszolgáltatottabbak a félrevezetésekkel, átverésekkel szemben (Friestad és Wright, 1994. Ezt 
a tényt ismerve nem meglepő, hogy számos bünöző kifejezetten idősekre szakosodott (Quinn, 2001).

A továbbiakban olyan, a kommunikációt nehezítő jellemzőket veszünk sorra, melyek a szakirodalom alapján magyarázhatják az idős személyek fokozott kiszolgáltatottságát, legalábbis nagy valószínűséggel hozzájárulhatnak ahhoz. Valamint olyan lehetőségeket összegzünk, melyek segíthetik egyéni vagy intézményes szinten a sérülékenység csökkentését.

Végül tömören bemutatjuk számos hazai interjú összegzett eredményeit, melyben idős emberek véleményét kérdeztük meggyőzési helyzetekről, megtévesztésről, valamint saját tapasztalataikra kérdeztünk rá. Ezek az eredmények tükrözik az érintettek szemléletét és a magyarországi helyzetet.

\section{A társas interakciót nehezítő jellemzők, s hatásuk a meggyőzési helyzetekre}

Vannak olyan fíziológiai jellemzők, melyek a test korosodásából fakadóan nehezítik a társas interakciót, ezekkel az orvosi megközelítésü gerontológia és a pszichológia társas kapcsolatokra koncentráló ága foglalkozik.

Az idősödéssel csökken a dopamin és a szerotonin szint, ami csökkenti az információ feldolgozásának és a munkamemóriának a kapacitását (Carpenter és Yoon, 2015; Salthause, 1996). Ez megnehezíti a fontos információk kiszürését a kommunikáció során (pl. Hedden és Yoon, 2006), valamint pontatlanná teszi a részletekre való emlékezést (Schacter, Koutstaal és Norman, 1997).

Továbbá az idősebb személyek gyakrabban támaszkodnak a heurisztikus feldolgozásra a problémamegoldás során, azaz első megítélésre jónak tűnő megoldást választanak (pl. Tversky és Kahneman, 1974), ami a döntések egy töredéke esetén komoly kockázattal jár (Hess, Rosenberg és Waters, 2001). Amikor motiváltak, nyilvánvalóan képesek megfontolt döntést hozni, de a szükséges motiváció nem mindig van jelen (pl. Carpenter és Yoon, 2017; Kim, Goldstein, Hasher és Zacks, 2005).

Mindezen tényezőkön túl, 50 éves kor fölött romlik a hallás, ami megnehezíti a mássalhangzók felismerését és a gyors beszéd megértését (Fozard, 1990), ami tovább rontja a kommunikáció hatékonyságát.

A nyugdíjas kor elérése után, az aktív életmód felhagyásával, különösképpen akkor, ha az idősödő ember életét krónikus betegségek nehezítik, a társas interakciók korlátozottabbá válnak (Shanas, 1968). A társas élet beszükülésével a személyek nyitottabbá válnak a társas helyzetekre (Lee és Geistfeld, 1999). 
A szocioökonómiai szelektivitás elmélet szerint (Carstensen, Isaacowitz és Charles, 1999) mindazok, akiknek limitált időperspektívája van (idősek vagy komoly betegséggel küzdő fiatalok) sokkal inkább nyitottak az érzelmekre és a pozitív ézelmi zárásra, mintsem a nyitott időperspektívával bírók (fiakalok, akív felnőttek). A nyitott időperspektíva az újdonság és információkereséssel jár inkább együtt. Ugyanakkor, kísérleti helyzetben bizonyítást nyert, hogy a limitált időperspektívával bírók a negatív keretezésű meggyőző üzeneteket preferálták, és jobban is emlékeztek rájuk, míg a nyitott perspektívával bírókra a pozitív keretezésü üzenetek hatottak jobban (Williams és Drolet, 2005).

Mind a társas kapcsolatok iránti fogékonyság, mind a pozitív érzelmi zárás igénye hozzájárulhat ahhoz, hogy a személyes megkeresési helyzetekben az idősek kevésbé képviselik saját érdekeiket, mint az aktív korú felnőttek. Harminc és hatvan éves kor között a legváltozatosabb a válaszrepertoár, amit a meggyőzési helyzetben alkalmaznak (Kirmani és Campbell, 2004). Ehhez képest a fiatalabbak, és az idősebbek egyaránt kevésbé változatos, s így kevésbé rugalmas válaszkészlettel bírnak.

Az életszakasz hipotézis (Visser és Krosnick, 1998) szerint a középkorúak a legkevésbé meggyőzhetőek, hozzájuk képest a fiatalok és az idősek is hajlamosabbak megváltoztatni eredeti viszonyulásukat. Ez leginkább a társasadalmi erővel magyarázható: jellemzően a középkorúak töltenek be magas státuszú pozíciókat, amivel együtt jár a folyamatos kapcsolattartás és döntések sora (Eaton, Visser, Krosnick és Ananad, 2009).

A közgazdaságtanban a meggyőzési helyzetekre vonatkozó szakirodalom két fontos pillanatot említ meg, ami az átverési helyzetben releváns. Az egyik annak a felismerése, hogy a folyamatban lévő társas helyzet egy meggyőzési helyzet (Friestad és Wright, 1994). A másik annak felismerése, hogy a másik fél nem etikus módon jár el, szándéka nem egyformán jó a meggyőzésben részt vevő személyeknek (Boush, Friestad és Wright, 2009). Az hogy ez a két pillanat mikor következik be, bekövetkezik-e egyáltalán, az a rendelkezésre álló kognitív kapacitásnak is függvénye, azaz összetett társas helyzetben az idősebb felnőttek sérülékenyebbek. Gyakran maguk is felismerik ezt, és ebből fakadóan kerülik a meggyőzési helyzeteket, vagy a meggyőzési helyzeteket gyorsan le akarják zárni (Kirmani és Campbell, 2004). Ez az idősek esetén gyakoribb megközelítés, mint a fiatalabb felnőttek esetén (Boush és mtsai., 2009).

\section{Az átverések kivédését segítő jellemzők}

Az egészséges életmód elősegíti a kognitív funkciók épségét. A táplálkozást tekintve a zöldségek, halak, olajos magvak fogyasztása előnyös egy átfogó metaanalízis szerint 
(Gutierrez and Isaacson, 2013). Ugyanez a kutatás a fizikai és társas aktivitást, valamint az esetleges cukorbetegség és vérnyomás kordában tartását javasolja a szellemi fittség megőrzése érdekében. Továbbá az is közismert, hogy a kristályos intelligencia (Cattell, 1987) magas szintje kompenzálhatja a fluid intelligencia szintjének a felnőttkor kezdetén megkezdődő fokozatos romlását (Bonifield és Cole, 2011).

Védőfaktort jelent még az időseket célzó átverésekkel szemben, ha a személynek magas a megismerési szükséglete (Cacioppo és Petty, 1982), azaz gyakran és szívesen gondolkodik, végez valamilyen "agytornát”. Elönyös ezeken kívül a magas önértékelés (O’Keefe, 2016), és a társas környezetnek való alacsony megfelelési igényszint (Perloff, 2010), ezek csökkentik az idős személyek kiszolgáltatottságát.

Számos intervenció segítheti az időskorúakat a meggyőzési helyzetekben, ha a személy részt vett ilyen programon, az növelheti védettségét a nem etikus megkeresésekkel szemben. Hatásos lehet a figyelmeztetés, hogy lehet, hogy megpróbálják majd adott módon meggyőzni (O’Keefe, 2016). Tulajdonképpen bármilyen olyan jellegü tevékenység hasznos, amikor tipikus átverésekre hívják fel a figyelmet.

Beoltásnak nevezik (O’Keefe, 2016) azt a technikát, amikor gyenge érvekkel támogatnak meg egy álláspontot, amit a meggyőző fél vélhetően képviselni fog, és ezáltal arra késztetjük a személyt, hogy maga gyártson ellenérveket. Ezáltal már felvértezve találja meg a valódi megkeresés. Ugyanakkor a visszautasítás tréningje is hatékony lehet, bár ez sem garantálja az éles helyzetben történő visszautasítást (O’Keefe, 2016).

Az Amerikai Egyesült Államokban az AARP Foundation (2003), egy idősek segítésére alakult szervezet, úgy találta, hogy a telemarketinges átverések több, mint fele az ötven év fölötti korosztály érinti, s ebből kiindulva intenzív kutatásba kezdtek. Úgy találták, hogy a gyakran megjelenő átverési technikák demonstrálása időnként sikeres technika, míg más esetekben ellentétes hatást váltott ki. Továbbá az átverhetőség demonstrálása sem volt hatásos stratégia, hiába mutatták meg nekik, hogy átverhetőek lennének, ez nem segítette az éles helyzetekben a viselkedést. A legcélravezetőbb eljárásnak az tünik a kísérletes vizsgálataik alapján, ha olyan kérdéseket sajátítanak el az idősek, amelyek annak feltérképezését segítik, hogy mennyire megbízható a másik fél. Továbbá a vizsgálataik összefoglalójában azt is kiemelik, hogy az önbizalom erősítése is hasznos, annak tudatosítása, hogy attól, hogy egyszer áldozattá váltak, az nem jelent semmit a jövőre nézve, hiszen mással is megesik, hogy rosszul dönt. 


\section{Empirikus vizsgálat}

Az adatelemzés célja a magyar időskorúak körében annak felmérése volt, hogy milyen meggyőzési helyzetekkel találkoznak általában, jellemzően hogyan reagálnak ezekre, és milyen védőfaktorok segíhetik a gyanús ajánlatok elutasítását, az átverések kivédését.

\section{Módszerek}

Az adatgyüjtés fogyasztóvédelmi témában zajlott, és interjúmódszerrel történt, elsősorban idős - 65 éves kor fölötti - személyek körében, leggyakrabban otthonukban. Az eredeti interjúkérdések tesztelése után, azaz saját interjúk felvételét követően, hallgatói asszisztenciával folytattuk az interjúfelvételt.

2018 tavaszán több egyetemi kurzus (Módszertan II., Reklámpszichológia labor- és terepgyakorlat) keretén belül azt a feladatot kapták a hallgatók, hogy vegyenek fel egy interjút, egy 65 év feletti személlyel fogyasztóvédelmi témában. Külön kérés volt, hogy lehetőleg ne közeli hozzátartozót keressenek meg, mert a közeli kapcsolat nehezíti a helyzet kontrollálását. A kurzusok keretén belül mindig sor kerül az interjúmódszer gyakorlására, ez esetben interjúvázlatot is kaptak a hallgatók. Aki nem szimpatizált ezzel a feladattal, alternatív interjút is felvehetett, így az senki számára nem volt kötelező.

Mind az idős személyek, mind a hallgatók számára van előnye ennek a feladatnak. A vizsgálati személyeknek felhívja a figyelmét az átverésekre, átbeszélhetik tapasztalataikat, lehetőséget nyújt a beszélgetés tapasztalataik feldolgozására. Továbbá az információk aktiválása révén a beszélgetést követő időszakban éberebben monitorozzák környezetüket, így vélhetően kisebb eséllyel válnak átverés áldozataivá. A hallgatók számára ez egy biztonságos közeg, a legtöbb idős örül a társaságnak, szívesen megnyílik, így az interjúhelyzet gyakorlására védett közegben történik. Nem utolsó sorban fejleszti a hallgatók empátiás és kommunikációs készségét, hiszen betekintést kapnak egy tőlük nagyban különböző életszakaszban lévő ember életébe. A hallgatók instruálása során külön felhívtuk a figyelmet arra, hogy ha a vizsgálati személy rosszul érezné magát, elfáradna, legyenek tekintettel rá, és vagy szakítsák meg az interjút, vagy mihamarabb zárják le azt, akár közbülső kérdések kihagyásával.

Eredetileg nem terveztük az adatok publikációját, az informatív interjúkat látva azonban nyilvánvalóvá vált ezen eredmények értéke. 


\section{Az interjúk menete}

Az interjú első szakaszában az interjút vezető személy rögzíti a téma szempontjából fontosnak gondolt személyes jellemzőket. Legelöször a demográfiai tényezőket: nemet, kort, legmagasabb iskolai végzettséget, a lakóhely típusát, valamint azt, hogy kivel él egy háztartásban a válaszadó.

Majd olyan kérdések következtek, melyek az önálló életvezetés különböző aspektusaira vonatkoztak: ki szokott főzni, vásárolni, ki váltja ki a gyógyszereket, milyen gyakran végzi ezeket a tevékenységeket. Ezután a társas élet különböző területeit térképezték fel a kérdezőbiztosok: milyen viszonyt ápol az interjúalany a szomszédokkal, jár-e nyugdíjas rendezvényekre, templomba, dolgozik-e, gyerekeivel, unokáival tartják-e a kapcsolatot. Végül az általános jellemzőre vonatkozó utolsó szakaszban a kommunikációs jellegzetességek feltérképezésére került sor: van-e telefonja, mire használja, jól boldogul-e vele; internetet használ-e, ha igen mire; televíziót néz-e, azon belül hírmüsorokat néz-e.

A következő szakasza az interjúknak a különböző ajánlatokkal való megkeresésekre vonatkozik: keresték-e meg gyanús ajánlattal, elfogadott-e olyan ajánlatot, amit megbánt és ennek az esetnek a részleteit. Milyen volt ez a helyzet, mi győzte meg, gyanús volt-e az ajánlat, kérdezett-e a termékről/szolgáltatásról, ha volt ilyen eset.

Ezután általánosan a telefonos megkeresésekről esik szó. Elmegy-e, ha hívják valahová, enged-e be olyan személyt, aki telefonon keresi meg. Kér-e további információt, hogyan viselkedik, és hogyan érzi magát ezekben a helyzetekben.

Végezetül az idősek félrevezetéséről általában kérdeztük az alanyokat. Azt szerettük volna megtudni, hogy látják-e értelmét a fogyasztóvédelmi programoknak; mit gondolnak, hogy miért célozzák sokan a csalók közül az időseket; és szerintük mi a leghatékonyabb stratégia az átverések kivédésére.

$\mathrm{Az}$ interjúk zárásaként minden interjúalany kapott egy kétoldalas tájékoztató füzetkét a legjellemzőbb csalások esetében célszerű viselkedésről, fogyasztóvédelmi panaszok kezeléséről, tájékozódási lehetőségekről. Minden interjúalany megkapta az interjút kivitelező személy és a kurzus felügyelőjének az elérhetőségét, ha utólag bármilyen kérdés felmerülne. Az interjúkat mindkét szerző áttekintette és így alakítottunk ki egy kódtáblát. A kódtáblát két doktori hallgató átnézte, és véglegesítette a kódolási kategóriákat. Végül egy kutatási asszisztens végezte el az interjúk kódolását. A statisztikai elemzések ezeken az adatokon alapulnak. 63 főt értünk el, 54 nőt és 11 férfit. Ez az arány részben a nagyobb női túlsúlyból 
fakadhat az adott korosztályban, részben pedig a nők általánosan tapasztalható fokozott válaszadási hajlandóságából. Az átlagéletkor 71,2 év ( $\mathrm{SD}=6,6$ év) volt, a legfiatalabb válaszadó 62 éves, a legidősebb 88 éves volt a megkérdezés időpontjában. A lakóhelyükre vonatkozó válasz 63 esetben érkezett, a válaszadók többsége városi lakos (38 fö), de számottevő a kisebb településeken lakó válaszadók száma is a mintában (21 fö) és budapesti válaszadóink is voltak (4 fö). A válaszadók döntő többsége vagy házastársával (28fö), vagy egyedül élt a megkérdezés időpontjában (25 fö), nagyobb családdal hat fó élt, illetve négyen gyermekükkel egy háztartásban.

\section{Eredmények}

A válaszadók közül 31-en beszélnek egy olyan esetről, ahol úgy érzik, hogy becsapták őket. A többi válaszadó vagy nem mesélt el ilyen esetet, vagy valaki más emlékezetes történetét mondta el. Ennek oka lehet az elmesélt helyzet kiugró jellege, vagy a saját esetek miatt érzett szégyenérzet. A továbbiakban azokra a helyzetekre koncentrálunk, ahol saját esetet meséltek a válaszadók. Telefonos megkeresés történt hat esetben, valamint egy esetben telefonos megkeresést követően más helyszínen vásárolt a vizsgálati személy.

Példaként a megkeresésekre ez utóbbi helyzetet leírjuk. Azt az ajánlatot kapta a telefonon megkeresett személy, hogy ha egy egészségügyi előadást meglátogat, akkor 30000Ft-ot kap egy levásárolható kártyán. A személy a helyszinre egy kisérövel érkezett. A helyszinen egy számítógépre csatlakoztatott müszer alapján ajánlottak nekik tablettákat (28000Ft/100 db), valamint egy szerkezetet, amivel a szemhéjára kellett fújni a levegöt, hogy az egyikük meggyógyulhasson. Ez a szerkezet annyira egyedülálló volt az eladók állitása szerint, hogy csak bérelnie lehetett (220000Ft/6 hó összegért és ígérték, hogy ezt majd visszakapja). Amikor rájöttek, hogy nem müködnek a gyógymódok, visszakérték a pénzüket, és megegyezés hiányában rendőrségi feljelentést tettek. A rendörség kideritette, hogy újracímkézett C vitamint vásároltak és egy hütö szagtalanitót lízingelt az egyikük.

15 esetben személyesen keresték fel őket otthonukban, valamint egy esetben személyes megkeresést követően történt más helyszínen megegyezés. Ez utóbbi esetben egy középkorú férfi és nő kereste meg otthonában az idős személyt. Nem engedte őket be, a kapuban beszélgettek. Egy termékbemutatóra hívták, jelezve, hogy ingyen termékmintákat kaphat és a gyermekeinek is jó ajándék lehet, amit ott kínálnak. Egy edénykészletet vásárolt a helyszínen, a reális árnál sokkal drágábban, amit később megbánt.

Három esetben a meggyőzés külső helyszínen zajlott, mint például termékbemutatón, egészségfelmérésen. Négy esetben más jellegű volt a helyszín, mint például Top Shop-os 
vásárlás; budapesti központba mentek el nyereményt átvenni; valamint két esetben a szomszédságba ment ki a telefonos megkeresés után az értékesítö, többekkel megbeszélve az alkalmat. Egy esetben pedig más helyszínen indult a meggyőzés és a személy otthonában zárult. Ekkor konkrétan a postán szólították le, és hazavitték, hogy egy edénykészletet mutassanak meg neki. Majd amikor nem vásárolt, a hazaszállításának költségét fizettették ki a vizsgálati személlyel.

A megkeresésekre jellemző, hogy vagy a vizsgálati személy, vagy házastársa egészségére hivatkozva próbálnak meg eladni egy terméket; vagy a gyermekekre, unokákra hivatkoznak. Nagyfokú kreativitást mutatnak az eladók abban, hogy mindenféle terméket egészségmegőrzés vagy gyógyítási céllal adjanak el. Gyakori, hogy büntudatot keltenek bennük (pl. sajnál ennyi pénzt a másiktól vagy az egészségére), vagy szégyenérzetet keltenek a potenciális vevőkben. Sok esetben az eladók kedvessége, rájuk szánt ideje, vagy az attól való félelem, hogy ők értettek félre valamit veszi rá az áldozatokat arra, hogy kifizessék a kért összeget. Az is jellemző, hogy egyszerüen nincs információjuk hasonló termékekről, és elhiszik, hogy ezt a minőséget, most olcsón lehet a kért nagy összegért megvenni. Viszont az egyértelmü átverések után a többség óvatosabban jár el, jellemző a megkeresések elutasítása, elzárkózás ezek elől. A kódolónk megítélése szerint 19 esetben nem lenne újra félrevezethető a vizsgálati személy a 31-ből. A megkérdezettek többsége kellemetlennek érzi a meggyőzési helyzeteket (36 fö), négyen kifejezetten idegesítőnek mondták azokat és további tíz fó is valamilyen más megfogalmazásban negatív érzésekről számol be (pl. zavaróak). A megtévesztések gyakoriságát az idősek hiszékenységével (24 fö említi), befolyásolhatóságával (21 fó) és magányosságával (9 fö) magyarázzák. A kis mintanagyság miatt óvatosan kell kezelni a statisztikai eredményeket, mindenesetre számos változó esetében megvizsgáltuk, hogy különbséget tesz-e azok közt, akik a kódolóink szerint továbbra is sérülékenyek, és azok közt, akik csak nehezen lennének félrevezethetőek.

Mindössze néhány esetben találtunk említésre méltó különbséget (Fisher-féle próbával), a védőfaktorok esetében egyet sem. Akkor történik meg valószínűbben az átverés, ha megnyerő a termék; ha jó üzletnek tünik a vétel; nagy szerencsének gondolják, hogy rájuk talált az ajánlat; vagy ha megnyerő az eladó $(p s<0,001)$. Ha a termék úgy tünik, hogy aktuális problémára adhat választ; valamint hiteles és lelkes az eladó (ps<0,05) szintén valószínübben történik vásárlás. A potenciális védőfaktorok egyike esetén sem találtunk egyértelmü bizonyítékot a hatékonyságra. Ez azonban nem zárja ki, hogy az így tapasztalt eltérések ne lennének fontosak, de ezek statisztikailag ezen a mintán nem voltak megragadhatóak. 
Érdemes azt is megemlíteni, hogy voltak olyan interjúk, amelyben kifejezetten aktív életet élő, fizikailag, vagy mentálisan korosztályukhoz képest kiemelkedő aktivitást mutató interjúalanyok beszéltek tapasztalataikról. Esetükben fel sem merült a sérülékenység gyanúja.

Összességében az alábbi következtetéseket vonhatjuk le:

1. Magyarországon is gyakoriak az időseket célzó megkeresések, ezek között nem ritkák a kifejezetten etikátlan átverések. Gyakran keresik meg őket ajánlatokkal a legkülönbözőbb helyszíneken, a telefonos ajánlatokat sokan említik, hogy zavarónak tartják. Ezek jellemzően az egészségre, vagy a családra hivatkozva próbálják termékeiket eladni.

2. A befejezett átverések leginkább személyes helyzetben történtek. Gyakrabban lesz sikeres az átverés, ha megnyerő termék, az eladó, valamint ha egy fennálló probléma megoldása lehet a termék, és kivételesnek tünik az ajánlat. Sokan beszámolnak arról, hogy büntudatot, szégyenérzetet keltenek bennük, vagy szégyellik, hogy későn ismerik fel a helyzetet és addig rabolták az eladó idejét. Az átverések után a többség, de nem mindenki „védettséget szerez”: óvatosabb lesz.

3. Az idősek maguk is tisztában vannak a sérülékenységükkel, a hiszékenységet, meggyőzhetőséget és magányt okolják elsősorban, és sokan közülük kerülik a meggyőzési helyzeteket.

4. Maga az egyetemi hallgatókkal kivitelezett interjúmódszer kifejezetten hasznosnak bizonyult. Hasznos az idősek számára, mert tudatosítja bennük a megtévesztések jellemzőit, a saját viselkedésüket ezekben a helyzetekben. Ugyanakkor fokozza a diákok empatikusságát, jobban megértik az idős emberek élethelyzetét és ráébreszti őket fogyasztóvédelmi sérülékenységükre, és felhívja a figyelmet a gyakori megkeresésekre, ami a családon belüli célzott kommunikációt fokozhatja.

\section{Megbeszélés}

A szakirodalmi áttekintés és empirikus vizsgálat célja az idősekkel fogyasztóvédelmi sérülékenységének mélyebb megértése volt. Összegezve az eredményeket azt mondhatjuk el, hogy számos biológiai jellmező (Carpenter és Yoon, 2015), valamint a korábbiakhoz képest kevésbé aktív társas életből fakadó sajátosság teszi az idősek egy részét kiszolgáltatottá az átverésekkel szemben (Lee és Geistfeld, 1999). Ezért is lenne nagyon fontos az aktív idősödés, azaz a fizikai, társas és szellemi aktivitás fenntartása. Az interjúk alapján a megkeresések gyakorisága zavaró, a sérülékenységet maguk is érzik, mégis, különösen 
személyes megkeresések esetén, többen beszámoltak arról, hogy maguk is félrevezethetőek voltak. A fogyasztóvédelmi programoknak célszerü lenne a tipikus átverések ismertetésén túllépni. Vannak, akik számára segítség, ha figyelmeztetik őket, vagy egy gyenge érveléssel hasonló módon megkörnyékezik őket, ahogy a potenciális megkeresés zajlani fog (O’Keefe, 2016). Azonban ezeknél hatékonyabb az önbizalom növelése és a specifikus kérdések megtanítása, amivel a gyanús ajánlatokat megszürhetik (AARP Foundation, 2003; O’Keefe, 2016). Az önbizalom növelése azért is fontos lehet, hogy a büntudat és szégyenérzet ellen hasson, melyet bennük kelteni kívánnak a beszámolók szerint, vagy amely annak hatására alakul ki, hogy nekezen ismerték fel a félrevezetést, vagy a kommunikáció valódi célját.

Sokan egészségügyi termékként eladott termékek vásárlásáról számolnak be, ami egy jellemző trükk, erre érdemes felhívni a figyelmet. Valamint a kivételes ajánlatok csábítása ösztönzi az ajánlatok elfogadását, ezért érdemes hangsúlyozni, hogy ez is egy jellemző csapda. Végezetül a fiatal hallgatók mint interjúztatók és idős interjúalanyok kombinációja egy ígéretes módszernek bizonyult. Többen beszámoltak a felek közül ennek hasznáról, értékéről, érdemes alkalmazni ezt a módszert. Ezzel a módszerrel, az adatok számosságát növelve, mind a hazai megkeresések jellegéről, mind a jellemző hárítási módokról, valamint az átveréseket megakadályozó tényezőkről is képet kaphatunk.

\section{Köszönetnyilvánítás}

Az Emberi Erőforrások Minisztériuma UNKP-18-3 kódszámú Új Nemzeti Kiválóság programjának támogatásával készült.

Köszönettel tartozunk az interjúkat kivitelező pszichológus hallgatóknak, valamint Gerhát Rékának, Nagy Lucának és Pap Dorka Eszternek az adatok kódolásában nyújtott segítségükért.

\section{Irodalom}

AARP Foundation (2003): Off the hook: Reducing participation in telemarketing fraud. Washington: AARP Foundation. Retrieved from: http://assets.aarp.org/rgcenter/consume/d17812_fraud.pdf

Baker, S. M., Gentry, J. W. Rittenburg, T. L. (2005): Building understanding of the domain of consumer vulnerability. Journal of Macromarketing, 25(2): 1-12.

Bonifield, C. M., Cole, C. A. (2011): Comprehension of Marketing Communications Among Older Consumers. In: The aging consumer: Perspectives from psychology and economics, pp. 175-189. Eds.: A. Drolet, N. Schwarz, C. Yoon, Routledge, New York. 
Boush, D. M., Friestad, M. Wright, P. (2009): Deception in the marketplace. Routledge, New York.

Cacioppo, J. T., Petty, R. E. (1982): The need for cognition. Journal of Personality and Social Psychology, 42: 116-131.

Campbell, M. C., Kirmani, A. (2008): I know what you're doing and why you're doing it: The use of the persuasion knowledge model in consumer research. In: Handbook of consumer psychology, pp. 549-575. Eds.: C. P. Haugtvedt, P. M. Herr, F. R. Kardes, Lawrence Erlbaum Associates, New York.

Carpenter, S. M., Yoon, C. (2015): Aging and consumer decision making. In: Aging and decision making, pp. 351-370. Eds.: T. M. Hess, J. Strough, C. E. Löckenhoff, Academic Press, Amsterdam.

Carpenter, S. M., Yoon, C. (2017): Ageing and consumer behavior: Challenges and opportunities. In: Routledge international handbook of consumer psychology, pp. 486-501. Eds.: C. V. Jansson-Boyd, M. J. Zawisza, Routledge, Oxon and New York.

Carstensen, L. L., Isaacowitz, D. M., Charles, S.T. (1999): Taking time seriously: A theory of socioemotional selectivity. American Psychologist, 54: 165-181.

Cattell, R. B. (1987): Intelligence: Its structure, growth and action. Elsevier, New York.

Eaton, A. A., Visser, P. S., Krosnick, J. A., Ananad, S. (2009): Social power and attitude strength over the life course. Personality and Social Psychology Bulletin, 35(12): 1646-1660.

Fozard, J. L. (1990): Vision and hearing in aging. In: Handbook of the psychology of aging, 3rd ed., pp. 150-170. Eds.: J. E. Binen K. W. Schiae, Academic Press, New York.

Friestad, M., Wright, P. (1994): The persuasion knowledge model: How people cope with persuasion attempts. Journal of Consumer Research, 21: 1-31.

Gutierrez, J., Isaacson, R. S. (2013): Prevention of cognitive decline. In: Handbook on the neuropsychology of aging. Eds.: L.D. Ravdin H. L. Katzen, Springer, New York.

Hedden, T., Yoon, C. (2006): Individual differences in executive processing predicts susceptibility to interference in verbal working memory. Neuropsychology, 20:511 528.

Hess, T., Rosenberg, D. C., Waters, S. J. (2001): Motivation and Representational Processes in Adulthood: The effects of social accountability and information relevance. Psychology and Aging, 16: 629-642. 
Kalache, A. (2001): Rural aging: Reduction of existing inequities. Journal of Rural Health, 17: $312-313$.

Kim, S., Goldstein, D., Hasher, L., Zacks, R. T. (2005): Framing effects in younger and older adults. The Journal of Gerontology: Series B: Psychological Science and Social Sciences, 60(4): 215-218.

Kirmani, A., Campbell, M. C. (2004): Goal seeker and persuasion sentry: How consumer targets respond to interpersonal marketing persuasion. Journal of Consumer Research, 31(3): 573-582.

Lee, J., Geistfeld, L. V. (1999): Elderly consumers' receptiveness to telemarketing fraud. Journal of Public Policy Marketing, 18(2): 208-217.

O’Keefe, D. J. (2016): Persuasion: Theory and research. Sage, Los Angeles.

Perloff, R. M. (2010): The dynamics of persuasion. Communication and attitudes in the 21st century. Routledge, New York.

Quinn, M. J. (2001): Friendly persuasion, good salesmanship or undue influence. Marquette Elder's Advisor, 2(4): 49-56.

Salthouse, T. A. (1996): The processing-speed theory of adult age differences in cognition. Psychological Review, 103: 403-428.

Schacter, D. L., Koutstaal, W., Norman, K. A. (1997): False memories and aging. Trends in Cognitive Sciences, 1: 229-236.

Shanas, E. (1968): Loneliness, isolation and desolation in old age. In: Old people in three industrial societies, pp. 271- 276. Eds.: E. Shanas, P. Townsend, D. Wedderburn, Atherton: New York.

Tversky, A., Kahneman, D. (1974): Judgment under uncertainty: Heuristics and biases. Science, 185: 1124-1131.

Valant, J. (2015): Consumer protection in the EU: Policy overview. European Parliamentary Research Service. Letöltve: http://www.europarl.europa.eu/RegData/etudes/IDAN/2015/565904/EPRS_IDA (2015)565904_EN.pdf

Visser, P. S., Krosnick, J. A. (1998): Development of attitude strength over the life cycle: Surge and decline. Journal of Personality and Social Cognition, 75(6): 1389-1410.

Williams, P., Drolet, A. (2005): Age-related differences in responses to emotional advertisements. Journal of Consumer Research, 32: 343-354. 